\title{
Angelika Felska
}

Uniwersytet Szczeciński

\section{Sprawozdanie z ogólnopolskiej konferencji naukowej Komu potrzebna jest szkoła wyższa? Indywidualność, lokalność, bolonizacja, europeizacja, 8-9 września 2016 r., Międzyzdroje}

Współczesność cechuje się permanentnymi zmianami i przeobrażeniami. Postęp cywilizacyjny odciska swoje piętno na wszelkich sferach życia ludzkiego. Także szkolnictwo wyższe poddawane jest ciągłym modyfikacjom, tak by dostosować je do potrzeb społecznych. Należy jednak mieć na uwadze heterogeniczność tego poziomu szkolnictwa. Klasyfikując uczelnie wyższe ze względu na ich specyfikę, można mówić o uniwersytetach, uniwersytetach przedmiotowych, akademiach czy wyższych szkołach zawodowych. Z kolei biorąc pod uwagę podmiot prowadzący, wskazać należy na uczelnie publiczne oraz niepubliczne. Można sklasyfikować ośrodki akademickie także ze względu na ich wielkość, wówczas będą to duże lub małe uczelnie etc. Taka niejednolitość w obszarze szkolnictwa wyższego w Polsce skutkowała wprowadzeniem przez organy nadzorujące wielu narzędzi służących do pomiaru jakości pracy uczelni. Wielu badaczy podkreśla zasadność formułowania pytań o współczesną szkołę wyższą, o to, jaka jest, komu i do czego potrzebna, jak jest jej przyszłość, jakie szanse i zagrożenia.

Biorąc pod uwagę te oraz inne nurtujące pytania, członkowie redakcji czasopisma „Pedagogika Szkoły Wyższej” wydawanego w Instytucie Pedagogiki Uniwersytetu Szczecińskiego zorganizowali po raz 22 ogólnopolską konferencję naukową. Temat konferencji brzmiał: Komu potrzebna jest szkoła wyższa? Indywidualność, lokalność, bolonizacja, europeizacja. Konferencja odbyła się w dniach 8-9 września 2016 roku w Międzyzdrojach. Patronat naukowy nad konferencją objął Komitet Nauk Pedagogicznych Polskiej Akademii Nauk. W skład Komitetu Naukowego konferencji weszło jedenastu naukowców, a całości przewodniczyła dr hab. Anna Murawska, prof. US, która otworzyła konferencję i podkreśliła, że Uniwersytet Szczeciński, a w szczególności badacze z Instytutu Pedagogiki, w zasadzie od początku jego istnienia zabiegali o podnoszenie jakości kształcenia akademickiego. Jednym z przejawów takiej troski było i jest organizowanie konferencji naukowych poświęconych tematowi pedagogiki szkoły wyższej. 
W konferencji uczestniczyli przedstawiciele 21 ośrodków uniwersyteckich i akademickich z całego kraju (m.in. Bydgoszcz, Cieszyn, Dęblin, Gdańsk, Katowice, Kielce, Koszalin, Kraków, Łódź, Olsztyn, Polkowice, Poznań, Szczecin, Toruń, Warszawa, Wrocław, Zielona Góra). Głos w debacie naukowej zabrało wielu profesorów, a wśród nich: Zbigniew Kwieciński z Dolnośląskiej Szkoły Wyższej, Maria Czerepaniak-Walczak z US, Barbara Kromolicka z US, Katarzyna Olbrycht z Uniwersytetu Śląskiego, Jolanta Miluska z US czy Wiesław Andrukowicz z US. Wydzielono dziewięć sekcji tematycznych oraz jedną sesję posterowa, podczas której swoje plakaty zaprezentowali doktoranci z Koła Naukowego Pedagogów US. Myślą przewodnią tej sesji było hasło Studia doktoranckie i doktoranci $w$ dyskursie prasowym.

Organizatorzy konferencji zadali uczestnikom ważne, nurtujące w ostatnich latach świat akademicki pytania. Po pierwsze, komu jest dziś potrzebna szkoła wyższa? Po drugie, do czego jest dziś potrzebna szkoła wyższa? Oraz - jaka szkoła wyższa jest dziś potrzebna?

W poszukiwaniu odpowiedzi na te i inne pytania zaproponowano płaszczyzny namysłu wokół zagadnień:

- indywidualne wartości, cele, aspiracje, potrzeby i status zarówno badaczy, jak i studentów,

- wartość, potrzeby, możliwości i tradycje lokalnych społeczności,

- wymagania, szanse, możliwości i bariery wynikające z ulokowania w Europejskim Obszarze Szkolnictwa Wyższego i Europejskiej Przestrzeni Badawczej.

Anna Murawska przywitała zgromadzonych gości, podziękowała za wsparcie oraz współpracę członkom Rady Naukowej Konferencji (prof. B. Kromolickiej, prof. M. Czerepaniak-Walczak oraz prof. Z. Kwiecińskiemu) reprezentującym jednocześnie Polską Akademię Nauk. Następnie przewodnicząca Komitetu Naukowego Konferencji oddała głos prof. B. Kromolickiej, która w imieniu dziekana Wydziału Humanistycznego US oficjalnie otworzyła debatę naukową i udzieliła głosu pierwszemu prelegentowi, prof. Z. Kwiecińskiemu. Podczas wystąpienia prof. Z. Kwieciński zwrócił uwagę słuchaczy na fakt, że współczesne społeczeństwo wychowujące jest dysharmonijne i wysoce niestabilne. W opinii profesora pedagogika obecnie nie nadąża za zmianami cywilizacyjnymi, co powoduje, że znajduje się ona w kryzysie. Bez zdiagnozowania źródła tego kryzysu nie jesteśmy w stanie sprostać współczesnym oczekiwaniom stawianym szkolnictwu wyższemu. A zatem, w opinii prof. Z. Kwiecińskiego, konieczna jest zmiana w kształceniu na poziomie wyższym.

Następnie wystąpiła prof. M. Czerepaniak-Walczak, która - podobnie jak jej przedmówca - wyraziła zdanie, że współczesny model uniwersytetu nosi wciąż znamiona XIX-wiecznej instytucji edukacyjnej i w związku z tym nie jest w stanie sprostać oczekiwaniom człowieka XXI wieku. Z uwagi na szeroki zakres tego problemu, prelegentka skupiła się jedynie na wątku szans i zagrożeń dla emancypowania się osób uczęszczających do szkół wyższych. Maria Czerepaniak-Walczak przedstawiła wyniki badań, w których 
uczestniczyło 125 studentów studiów I i II stopnia, udzielających odpowiedzi na pytanie: jak zmienię świat po skończeniu studiów? Metodą badawczą była analiza swobodnych pisemnych wypowiedzi studentów. Wyniki badań ukazały zarówno szanse, jak i zagrożenia dla emancypacji w toku edukacji w szkole wyższej. Jednak liczba zagrożeń była wyższa aniżeli szans.

Po przerwie obrady rozpoczęło wystąpienie prof. B. Kromolickiej pod tytułem: Zaangażowanie studentów $w$ proces uniwersyteckiego ksztatcenia. Analiza danych statystycznych oraz treści, jakie zostały zaprezentowane, jednoznacznie świadczą o niskim poziomie zaangażowania studentów w proces kształcenia w uczelni wyższej. Jednak, jak zwróciła uwagę prelegentka, aby mogła zaistnieć zmiana w tym obszarze, niezbędne jest przewartościowanie nastawienia kadry akademickiej do studentów oraz procesu nauczania/kształcenia. Jak zauważyła prof. B. Kromolicka: „dziś nie idzie już o to, żeby uczynić z każdego studenta potencjalnego naukowca przyszłości, ale o to, aby zmotywować do sensownej nauki, do sensownego uczenia się, które zaowocuje przemianą edukacyjną, dającą kiedyś zysk samemu kształcącemu się". Aby tak się mogło stać, uczelniom wyższym potrzebni są kreatywni nauczyciele akademiccy, którzy w swojej pracy zaktywizują studentów poprzez edukację z wykorzystaniem tematycznych projektów oraz posłużą się podejściem SCL (Student Centered Learning), czyli kształceniem skoncentrowanym na studencie, uwzględniającym potrzeby, zainteresowania, aspiracje i kontekst kulturowy życia studentów.

Na zakończenie II sesji głos zabrała prof. K. Olbrycht z UŚ, której tematem wystąpienia były: Pola dyskusji wokót wartości mniejszych ośrodków akademickich (na przykładzie cieszyńskiego ośrodka Uniwersytetu Ślaskiego). Prelegentka zasygnalizowała problem roli i miejsca mniejszych ośrodków i środowisk akademickich w polskim systemie szkolnictwa wyższego. Problemem tych środowisk są pojawiające się pytania o zasadność ich istnienia. Sceptycy mówią o wysokich kosztach ich utrzymania, optymiści podkreślają ich ważną rolę w środowisku lokalnym.

Sesja III oraz IV odbywały się równolegle. Moderatorami sesji III byli prof. dr hab. Dariusz Kubinowski z US oraz dr hab. Jan Rutkowski z Uniwersytetu Warszawskiego. Obaj profesorowie zaprezentowali swoje wystąpienia, po czym głos oddali kolejnym prelegentom. Wśród nich znaleźli się: dr hab. Helena Ostrowicka i dr Elżbieta Okońska z Uniwersytetu Kazimierza Wielkiego w Bydgoszczy oraz mgr Jarosław Jendza z Uniwersytetu Gdańskiego. Wszystkie wystąpienia oscylowały wokół konfliktu wartości i funkcji szkoły wyższej oraz obrazu uczelni wyższej, jaki wyłania się z dyskursu prasowego oraz z przebiegu dyskusji naukowych w trakcie konferencji naukowych.

Sesja IV była moderowana przez dr hab. Elżbietę Perzycka, prof. US oraz dr hab. Arkadiusza Żukiewicza z Uniwersytetu Łódzkiego. W tej części obrad tematy związane były z nowymi technologiami w uczelniach wyższych (wystąpienie dr hab. Elżbiety Perzyckiej z US) oraz tym, czy uczelnie te przygotowują swoich absolwentów do faktycznych potrzeb rynku pracy i wszechobecnej ekonomizacji (referaty dr hab. Arkadiusza Żukiewicza z UŁ, $\mathrm{dr}$ hab. Wojciecha Jareckiego, prof. US, dr Małgorzaty Mikut z US, dr Wiktora Sawczuka 
z Uniwersytetu Warmińsko-Mazurskiego, dr Michała Kwiatkowskiego z Akademii Pedagogiki Specjalnej).

W ramach kolejnej sesji swoje wystąpienia zaprezentowało ośmiu prelegentów. Moderatorami w tej grupie była prof. K. Olbrycht z UŚ oraz dr hab. Elżbieta Magiera prof. US. Pierwsza zaprezentowała swój referat prof. Magiera, która próbowała odpowiedzieć na pytanie: Komu byty potrzebne uniwersytety $w$ Drugiej Rzeczypospolitej? Interesujące było także wystąpienie dr Anny Mańkowskiej z Uniwersytetu im. A. Mickiewicza w Poznaniu, która przedstawiła problemy i dylematy prywatnego szkolnictwa wyższego w Chinach. Kolejne dwa wystąpienia, dr Iwony Cymerman z Uniwersytetu Warmińsko-Mazurskiego oraz dr Pauli Wiażewicz-Wójtowicz z US, związane były z kształceniem studentów na kierunku: pedagogika wczesnoszkolna i przedszkolna. Pierwsza z referentek wykazała zależność pomiędzy uniwersytetem (a konkretnie jego studentami odbywającymi praktyki zawodowe) a przedszkolem. Z kolei dr P. Wiażewicz-Wójtowicz podjęła temat działalności artystycznej i aktywności twórczej w uniwersytecie. Następnie dr Andrzej Marciniuk dokonał analizy dydaktyki lotniczej II RP przed wrześniem 1939 roku i wynikającego z niej przesłania dla współczesnej „Szkoły Orląt”. Mgr Angelika Felska podjęła próbę odpowiedzi na pytanie, czy współczesny uniwersytet ludowy jest reliktem czy raczej szkołą przyszłości?

Sesja VI moderowana była przez dr hab. Ryszardę Cierzniewską z Uniwersytetu Kazimierza Wielkiego w Bydgoszczy oraz dr Tomasza Zimnego z US. W tej grupie prelegenci rozważali kwestie związane z zależnościami, jakie zachodzą (a może i nie) pomiędzy technologiami a edukacją akademicką (dr hab. R. Cierzniewska) oraz czy współczesny student jest jednocześnie klientem uczelni wyższej (dr Magdalena Barańska z Uniwersytetu Adama Mickiewicza). Dr Lidia Marek (US) prezentowała współczesne efekty kształcenia w zakresie kompetencji społecznych kształtowanych na poziomie uczelni wyższych. Poruszono także kwestię nowelizacji ustawy o szkolnictwie wyższym (mgr Wioleta Adamczyk-Bębas z Wyższej Szkoły Handlowej w Radomiu) oraz możliwości kontrolowania i oceniania efektów kształcenia studentów (dr hab. Tomasz Zimny z US).

W drugim dniu konferencji organizatorzy ponownie przywitali gości oraz zaprosili do kontynuowania wspólnej debaty naukowej dotyczącej tego, komu potrzebna jest współcześnie szkoła wyższa?

Sesja VII była prowadzona przez dr hab. Annę Sajdak z Uniwersytetu Jagiellońskiego oraz dr hab. Janinę Świrko-Pilipczuk, prof. US. Wystąpienia związane były z szeroko pojętą dydaktyką akademicką. Dr hab. A. Sajdak poddała rozwadze kwestię paradygmatu humanistycznego w dydaktyce akademickiej, zadając pytanie, czy to utopia, konieczność, a może szansa? Z kolei wystąpienie dr hab. Ewa Szadzińska poświęcone było tematowi: Zjawiska „zderzenia kultur” w uniwersytecie a wyznacznika zmian dydaktyki akademickiej. Dr Dorota Jankowska mówiła o tym, czego tak naprawdę uczy współczesnych studentów codzienność akademicka.

Sesja VIII moderowana była przez dr hab. Ewę Bochno z Uniwersytetu Zielonogórskiego oraz dr hab. Dorotę Sieroń-Galusek z UŚ. Tematyka tej sesji oscylowała wokół proble- 
mów studentów, ich wyborów, autokreacji i samoświadomości, myślenia biograficznego (dr hab. D. Sieron-Golusek), funkcjonowania w grupach studenckich (dr hab. E. Bochno), kreowania przez nich własnej egzystencji (dr hab. A. Murawska, prof. Uniwersytetu Szczecińskiego), szans rozwojowych (dr Dorota Pauluk z Uniwersytetu Jagiellońskiego), samoświadomości (dr Janusz Ślusarski ze Szkoły Orląt w Dęblinie) czy ich zaangażowaniem, a może raczej obojętnością w podejmowaniu wyborczych decyzji (dr Ilona Kość z US).

Ostatnia sesja konferencji, prowadzona przez prof. J. Miluską (US) oraz prof. W. Andrukowicza (US), poświęcona była w całości funkcjonowaniu współczesnej uczelni wyższej. Prelegenci zastanawiali się nad misją i współczesną rolą szkoły wyższej (dr Wioleta Bryniewicz), jej autonomią (dr hab. Andrzej Sowiński) czy wszechobecnym mitem indywidualizacji na uniwersytecie (prof. W. Andrukowicz). Niezwykle interesująca była krótka debata o „pożytkach” płynących z akademii, w której uczestniczyli młodzi badacze z Uniwersytetu Gdańskiego (dr Karolina Starego), Uniwersytetu Karola Wielkiego w Bydgoszczy (dr Łukasz Stankiewicz) oraz Uniwersytetu Szczecińskiego (dr Jacek Moroz, dr Maksymilian Chutorański i dr Oskar Szwabowski).

Kończąc konferencję, ponownie podkreślono zasadność wielokrotnie przywoływanego pytania: Komu potrzebna jest szkoła wyższa? W opinii organizatorów konferencji i jej uczestników środowisko akademickie wymaga i domaga się nieustannej i głębokiej refleksji, uprawniającej do odpowiedzi na to pytanie. 